\title{
Carotenoids and cholesterol in membranes of Mycoplasma laidlawii
}

\author{
By S. RAZIN* and the late R. C. ClEVERDON \\ Department of Bacteriology, the University of Connecticut, Storrs, U.S.A.
}

(Received 12 August 1965)

\begin{abstract}
SUMMARY
Carotenoids synthesized by Mycoplasma laidlawii and cholesterol incorporated from the growth medium were confined to the cell membrane. Increased carotenogenesis induced by addition of sodium acetate to the growth medium, or inhibition of carotenogenesis by thallium acetate or diphenylamine did not affect the incorporation of cholesterol into membrane lipids. Growth of the organisms in media with various amounts of cholesterol modified the cholesterol content of the membranes with no significant effect on carotenoid formation. These results indicate that carotenoids do not interfere with the incorporation of cholesterol into $\boldsymbol{M}$. laidlawii membranes.
\end{abstract}

\section{INTRODUCTION}

Mycoplasma cells are limited by a thin lipoprotein 'unit membrane' (Razin, 1963) which can be isolated following osmotic lysis of the organisms (Razin, Argaman \& Avigan, 1963). The saprophytic Mycoplasma laidlawii strains are especially suited for preparation of membranes, because they grow faster than the other mycoplasmas, and are very sensitive to osmotic shock. Membranes of $M$. laidlawii were therefore the subject for recent studies on membrane composition (Razin, et al. 1963), membrane subunits (Razin, Morowitz \& Terry, 1965) and enzymic activities (Pollack, Razin \& Cleverdon, 1965). The results of these investigations advocate the use of Mycoplasma membranes as models for studying the properties of biological membranes in general. The ability of mycoplasmas to incorporate substantial amounts of cholesterol from the growth medium into their membrane lipids can be exploited in studies of the function of cholesterol in biological membranes. M. laidlarvii may be especially suited for this purpose as the amount of cholesterol in its membrane can be easily regulated by varying the concentration of cholesterol in the growth medium. M. laidlawii was found, however, to incorporate much smaller amounts of free cholesterol than the parasitic mycoplasmas, and was practically incapable of incorporating cholesteryl esters (Argaman \& Razin, 1965). M. laidlarwii strains differ from the parasitic Mycoplasma in their ability to grow without added cholesterol (Razin \& Knight, 1960) and synthesize carotenoids located in the cell membrane (Rothblat \& Smith, 1961; Razin et al. 1963; Smith, 1963a). Smith (1963b) postulated that carotenoids in the saprophytic Mycoplasma fulfill the same roles as that of cholesterol in the parasitic strains. Among the arguments brought by Smith to support his hypothesis were the resemblance of the hydrocarbon structure

* Present address: Department of Clinical Microbiology, the Hebrew University Hadassah Medical School, Jerusalem, Israel. 
of carotenoids and cholesterol (Smith, 1963 b) and the finding that PPLO-serum fraction, when added to the growth medium of $M$. laidlawii, suppressed carotenogenesis (Smith, 1963a). This finding was interpreted by Smith as a sparing effect of cholesterol, included in the PPLO-serum fraction, on the synthesis of carotenoids. The above arguments led us to suggest that the carotenoids may interfere with cholesterol uptake by occupying the same sites in the membrane, thus explaining the low cholesterol content of $M$. laidlarvii (Argaman \& Razin, 1965). The purpose of the present investigation was to test this suggestion.

\section{METHODS}

Organism. Mycoplasma laidlarwii strain B (PG9) obtained from Dr D. G. ff. Edward (Wellcome Research Laboratories, Beckenham, Kent) was used throughout this work.

Growth conditions. The basal growth medium was tryptose broth consisting of (g/l.): Bacto-tryptose, 20; sodium chloride, 5; tris (2-amino-2-hydroxymethylpropane-1:3-diol), 5; glucose, 7 ; and penicillin $\mathrm{G}$ (crystalline) 100,000 units. The pH of the medium was $8 \cdot 2$ to 8.4 without adjustment. All other supplements to the growth medium were added as sterile solutions. The same batch of Difco PPLO-serum fraction was used in all experiments, to avoid variations in the cholesterol content of this medium component. Cholesterol (Calbiochem, Los Angeles, California, U.S.A.) was recrystallized twice from ethanol, dissolved in Tween 80. and added to the growth medium. Various amounts of an ethanolic solution of cholesterol $(20 \mathrm{mg} . / \mathrm{ml}$.) were mixed with a constant volume of Tween $80(10 \%, v / v)$, heated to complete solution and added to the growth medium. By this method up to $20 \mathrm{mg}$. of cholesterol in $1 \mathrm{ml}$. ethanol could be dissolved in $1 \mathrm{ml}$. of Tween $80(10 \%, \mathrm{v} / \mathrm{v})$, and remain in solution on addition to 1 l. of the growth medium. A solution of $10 \%(w / v)$ bovine albumin fraction V (Calbiochem) was prepared in de-ionized water, sterilized by filtration, and added to the growth medium in a final concentration of $0 \cdot 1 \%(w / v)$ to neutralize the toxicity of the Tween 80 .

Growth was done in 11 . volumes of medium dispensed in 2 l. flasks incubated statically at $37^{\circ}$ for $20-24 \mathrm{hr}$. The organisms were harvested by centrifugation at $9000 \mathrm{~g}$ for $15 \mathrm{~min}$. and washed once in $\beta$-buffer (Pollack, Razin, Pollack \& Cleverdon, 1965) consisting of: sodium chloride, $0.15 \mathrm{M}$; tris, $0.05 \mathrm{M}$; 2-mercaptoethanol, $0.01 \mathrm{M}$ in de-ionized water, adjusted to $\mathrm{pH} 7 \cdot 4$ with $\mathrm{HCl}$.

Isolation of cell membranes. The washed organisms obtained from 11 . medium were lysed by resuspension in $40 \mathrm{ml}$. of de-ionized water (Razin, 1964). The suspension was incubated at room temperature for $30 \mathrm{~min}$. and then centrifuged at $\mathbf{3 7 , 0 0 0 \mathrm { g }}$ for $30 \mathrm{~min}$. to collect the membranes. The membranes were washed once in $40 \mathrm{ml}$. of de-ionized water and resuspended in $10 \mathrm{ml}$. de-ionized water. Membrane protein was determined in a $\mathbf{0 . 2} \mathrm{ml}$. sample of this suspension according to Lowry, Rosebrough, Farr \& Randall (1951).

Estimation of carotenoids. Part of the membrane suspension (usually one-fifth) was centrifuged at $37,000 \mathrm{~g}$ for $30 \mathrm{~min}$. The resulting pellet was extracted with $7 \mathrm{ml}$. of boiling ethanol for $10 \mathrm{~min}$. in the dark and under a nitrogen atmosphere (Rothblat, Ellis \& Kritchevsky, 1964). The extracted membranes were removed by centrifugation and the extinction at $4.42 \mathrm{~m} \mu$ of the supernatant fluid was measured 
in a Beckman DB spectrophotometer. Extraction of the carotenoids from wet membrane material with boiling ethanol was found superior to extraction of freezedried membranes with chloroform + methanol $(2+1$, by vol.). The absorption spectrum of Mycoplasma laidlawii carotenoids measured in ethanol showed absorption maxima at 418, 442 and $472 \mathrm{~m} \mu$; the peak at $442 \mathrm{~m} \mu$ was the highest. The amount of carotenoid pigments in membranes was expressed therefore as extinction at $442 \mathrm{~m} \mu \times 1000$ per mg. membrane protein or per mg. dry-weight of membrane material.

Estimation of cholesterol. The residual part of the membrane suspension was centrifuged at $37,000 \mathrm{~g}$ for $30 \mathrm{~min}$. The resulting pellet was freeze-dried and weighed. Lipids were extracted from the freeze-dried material by a chloroform + methanol mixture $(2+1$, by vol.) as described previously (Argaman \& Razin, 1965). Cholesterol in the lipid was separated by thin-layer chromatography and determined by the $\mathrm{FeCl}_{3}$ method (Argaman \& Razin, 1965).

\section{RESULTS}

\section{Location of carotenoids and cholesterol in the cell}

The confinement of the carotenoids and cholesterol to the cell membrane of Mycoplasma laidlawii was demonstrated in an experiment in which the same batch of organisms was divided into two equal portions. One portion was osmotically lysed and the membranes recovered quantitatively and freeze-dried. The other portion of

\section{Table 1. Total lipid, carotenoids and cholesterol in cells and} membranes of Mycoplasma laidlawii

Cells were grown in 21 . of tryptose broth supplemented with $1 \%$ (v/v) PPLO-serum fraction. The cells were harvested after $24 \mathrm{hr}$ incubation at $37^{\circ}$, washed twice in $\beta$ buffer and divided into two equal portions. One portion was osmotically lysed and the membranes recovered quantitatively and freeze-dried. The other portion of the cells was freeze-dried without any prior treatment. Total lipid, carotenoids and cholesterol were determined in the dried material as described under Methods.

\begin{tabular}{|c|c|c|c|c|}
\hline & $\begin{array}{l}\text { Total } \\
\text { dry wt. } \\
\text { (mg.) }\end{array}$ & $\begin{array}{l}\text { Total } \\
\text { lipid } \\
\text { (mg.) }\end{array}$ & $\begin{array}{c}\text { Carotenoids } \\
\left(\mathbf{A}_{\mathbf{4 4 2}} \times 1000 / \mathrm{mg}\right. \\
\text { lipid })\end{array}$ & $\begin{array}{l}\text { Cholesterol } \\
\text { ( } \mu \mathrm{g} \cdot / \mathrm{mg} . \text { lipid) }\end{array}$ \\
\hline Whole cells & $221 \cdot 9$ & $25 \cdot 8$ & $65 \cdot 1$ & $22 \cdot 3$ \\
\hline Membranes & $73 \cdot 0$ & $26 \cdot 0$ & $64 \cdot 6$ & $23 \cdot 4$ \\
\hline
\end{tabular}

cells was freeze-dried without previous treatment. Table 1 shows that the membrane fraction, which constituted about $32 \%$ of the total dry weight of the organisms, contained practically the same amount of total lipid, carotenoids and cholesterol as the whole organisms, Hence, carotenoids and cholesterol seem to be exclusive constituents of the cell membrane of $M$. laidlarvii.

\section{Effect of variations in carotenogenesis on cholesterol uptake}

Rothblat \& Smith (1961) reported that the addition of $0.5 \%(w / v)$ of sodium acetate to the growth medium increased carotenoid formation by $M$. laidlawii. Figure 1 shows that the addition of increasing amounts of sodium acetate to tryptose broth increased pigment formation very markedly. The increase in the caro- 
tenoid content of the membranes had no significant effect on the amount of cholesterol incorporated into the membranes from the growth medium. Sodium acetate showed some growth inhibition, reflected by the decrease in the yield of membrane material (Fig. 1).

\section{Table 2. Effects of inhibitors of carotenogenesis on the cholesterol content of Mycoplasma laidlarwii membranes}

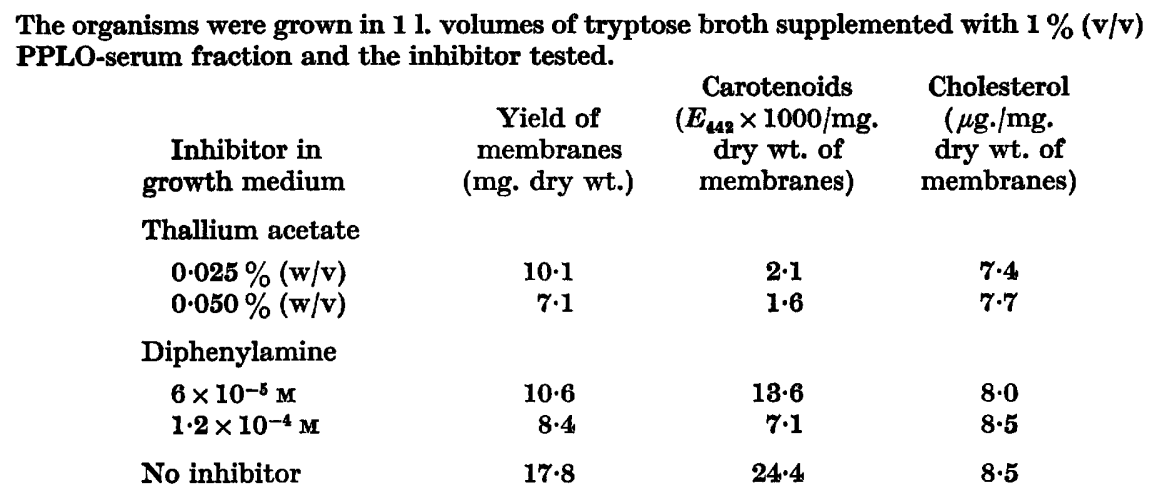

Thallium acetate was found to inhibit markedly pigment formation by $M y c o-$ plasma laidlarwii (observed originally by J. D. Pollack). Diphenylamine also decreased significantly the amount of carotenoid pigments produced by the organisms. Both agents inhibited the growth of the test organism as well (Table 2). Inhibition of pigmentation by diphenylamine was reversible to a certain extent, since the organisms which were completely devoid of pigment when harvested, turned yellow on subsequent washings. Decreased of pigmentation by the inhibitors was not accompanied by any significant change in the amount of cholesterol incorporated into the cell membrane (Table 2).

\section{Effect of variations in the cholesterol content of the membranes on carotenogenesis}

PPLO-serum fraction serves as a source for cholesterol in many growth media for Mycoplasma. The amount of cholesterol incorporated into the membranes of Mycoplasma laidlawii increased from nearly zero in the tryptose medium without PPLO-serum fraction, to a maximum of about $8 \mu \mathrm{g} . / \mathrm{mg}$. dry weight of membranes when the concentration of PPLO-serum fraction in the medium reached $2 \%(v / v)$. Some decrease in the carotenoid content of the membranes was noticed when the concentration of PPLO-serum fraction in the medium was increased, confirming previous results of Smith (1963a). PPLO-serum fraction improved the growth of $M$. laidlawii in tryptose broth, as reflected by the increase in membrane yield (Fig. 2).

To test whether the decrease in carotenoids caused by PPLO-serum fraction was dependent on its cholesterol component, cholesterol itself was added to the growth medium instead of PPLO-serum fraction. Table 3 shows that the amount of cholesterol incorporated into the membranes increased with the increase of its concentra- 
tion in the growth medium, reaching about the same value (above $7 \mu \mathrm{g}$ cholesterol/ mg. dry weight of membranes) obtained with PPLO-serum fraction. The amount of carotenoids in the membranes was not affected to any significant degree by the changes in the cholesterol content of the membranes (Table 3).

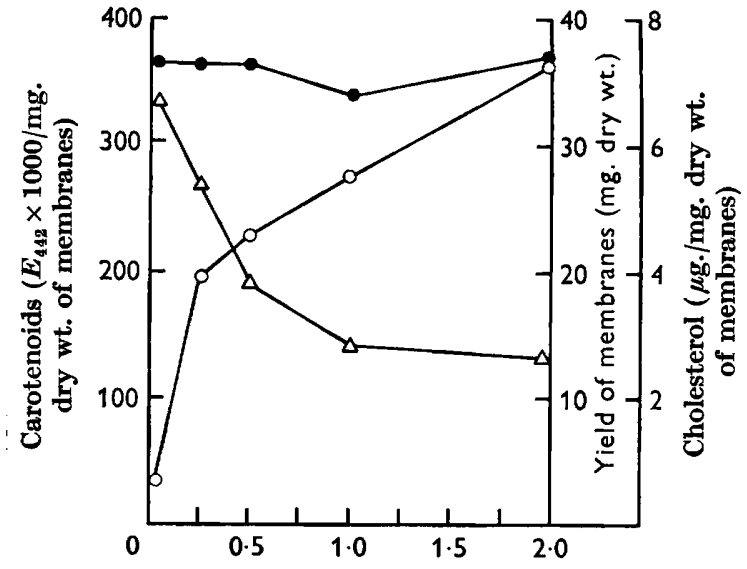

Sodium acetate in growth medium $(\%, w / v)$

Fig. 1

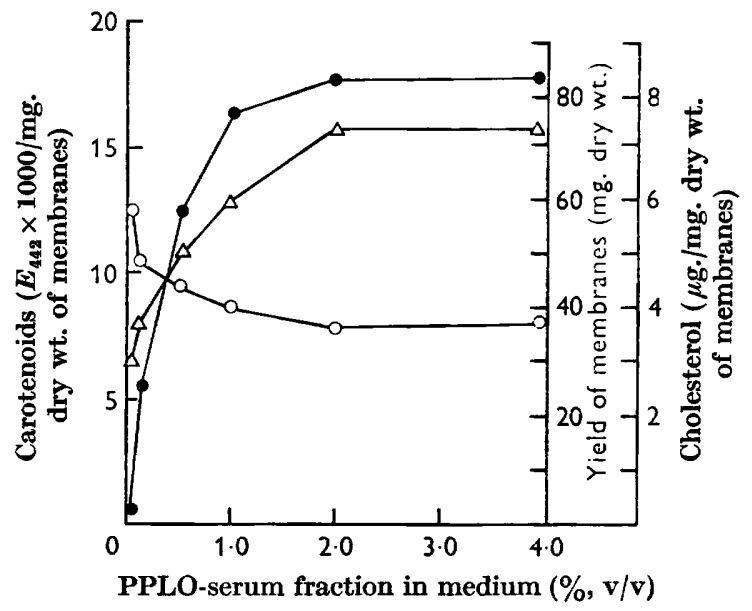

Fig. 2

Fig. 1. Effect of sodium acetate added to the growth medium on the carotenoid and cholesterol content of Mycoplasma laidlawii membranes. The organisms were grown in 1 l. volumes of tryptose broth supplemented with $1 \%(v / v)$ PPLO-serum fraction and various amounts of sodium acetate. Cholesterol (O); carotenoids (O); membrane yield $(\Delta)$.

Fig. 2. Effect of PPLO-serum fraction added to the growth medium on the carotenoid and cholesterol content of Mycoplasma laidlawii membranes. The organisms were grown in 11 . volumes of tryptose broth supplemented with various amounts of PPLO-serum fraction. Cholesterol $(O)$; carotenoids $(O)$; membrane yield $(\Delta)$.

Table 3. Effect of cholesterol added to the growth medium on the carotenoid and cholesterol content of Mycoplasma laidlawii membranes

The organisms were grown in 11. volumes of tryptose broth supplemented with $0.1 \%(w / v)$ bovine albumin fraction $V$ and various amounts of cholesterol dissolved in Tween 80. The final concentration of Tween 80 in the medium was $0.01 \%(v / v)$.

\begin{tabular}{|c|c|c|c|}
\hline $\begin{array}{l}\text { Cholesterol } \\
\text { added to } \\
\text { medium } \\
(\mu \mathrm{g} . / \mathrm{ml} .)\end{array}$ & $\begin{array}{c}\text { Yield of } \\
\text { membranes } \\
\text { (mg. dry wt.) }\end{array}$ & $\begin{array}{c}\text { Carotenoids } \\
\left(E_{442} \times 1000 / \mathrm{mg} .\right. \\
\text { dry wt. of } \\
\text { membranes })\end{array}$ & $\begin{array}{l}\text { Cholesterol } \\
\text { ( } \mu \mathrm{g} \cdot / \mathrm{mg} . \\
\text { dry wt. of } \\
\text { membranes })\end{array}$ \\
\hline 0 & $57 \cdot 2$ & $23 \cdot 1$ & 0.3 \\
\hline 0.5 & $66 \cdot 0$ & $26 \cdot 1$ & $2 \cdot 8$ \\
\hline 2.5 & $64 \cdot 8$ & $20 \cdot 8$ & 4.7 \\
\hline $5 \cdot 0$ & $52 \cdot 8$ & $24 \cdot 6$ & $7 \cdot 2$ \\
\hline $10 \cdot 0$ & $48 \cdot 3$ & 23.8 & $7 \cdot 8$ \\
\hline $20 \cdot 0$ & $42 \cdot 7$ & $20 \cdot 2$ & $7 \cdot 1$ \\
\hline
\end{tabular}

\section{DISCUSSION}

Cholesterol and carotenoids seem to be restricted to the cell membrane in $M y c o-$ plasma laidlawii. Rothblat \& Smith (1961) reported that only about $70 \%$ of the cell cholesterol and $80 \%$ of the carotenoids could be found in the insoluble fraction 
or 'membrane fraction' of $\boldsymbol{M}$. laidlawii and the rest in the 'soluble fraction'. In light of the recent work of Pollack et al. (1965) it seems that the 'soluble fraction' analysed by Rothblat \& Smith contained small membrane fragments, not sedimentable by centrifugation at $30,000 \mathrm{~g}$ for $20 \mathrm{~min}$., resulting from disruption of the delicate membranes by the sonic treatment. Osmotic lysis of the organisms, used in the present work, has been shown to be preferable for the separation of membranes from other cell constituents (Pollack et al. 1965). Our data show that M. laidlawii under the growth conditions tested was capable of incorporating cholesterol up to a value of $7-8 \mu \mathrm{g} / \mathrm{mg}$. dry weight of membranes, corresponding to about $3 \%$ by weight of the total membrane lipids. Thus, cholesterol seems to be a minor component of M. laidlawii lipids. In parasitic Mycoplasma cholesterol was found to constitute up to one third of membrane lipids (Argaman \& Razin, 1965). The carotenoid pigments are apparently also minor components of $\boldsymbol{M}$. laidlawii lipids. Preliminary experiments to determine the pigments gravimetrically, following chromatographic separation, have indicated that they constitute $1-3 \%$ of the total membrane lipids (Razin, unpublished results).

No attempt was made in the present work to determine non-pigmented, more saturated, carotenoids in Mycoplasma laidlawii. They were certainly present in organisms grown with diphenylamine, known to inhibit the final oxidative stages in carotenogenesis leading to formation of the more unsaturated pigmented products (Cho, Corpe \& Salton, 1964; Rilling, 1965). Removal of the inhibitor during the washing of organisms and derived membranes resulted in some pigment formation, apparently due to oxidation of the saturated carotenoids accumulated during growth with diphenyl-amine. We do not as yet know the stage or stages of carotenogenisis inhibited by thallium acetate. The marked reduction in growth of $\boldsymbol{M}$. laidlawii caused by thallium acetate, in concentrations used routinely in selective media for Mycoplasma, suggests the omission of this agent from growth media for Mycoplasma whenever possible.

Our experiments did not show any relationship between the amount of carotenoid pigments and that of cholesterol in Mycoplasma laidlawii membranes. The amount of either of these components could be markedly changed without affecting that of the other. Decreased carotenogenesis following the increase in PPLOserum fraction concentration in the growth medium does not involve the cholesterol component of this medium supplement. The lower capacity of the saprophytic Mycoplasma to incorporate cholesterol does not seem thus to depend on the presence of carotenoid pigments in their membranes. The explanation for this phenomenon may rather involve differences in phospholipid composition between the saprophytic and parasitic strains. Phospholipids form the major lipid component of Mycoplasma membranes (Morowitz et al. 1962; Razin et al. 1963). The two major fractions of $M$. laidlawii strain B phospholipids were found to contain covalently bound glucose (Smith \& Henrikson, 1965) differing from the phospholipid composition of the parasitic $M$. gallisepticum as reported by Tourtellotte, Jensen, Gander \& Morowitz (1963).

Contribution No. 124 of the Institute of Cellular Biology, University of Connecticut. One of the authors (S.R.) held a Senior Foreign Scientist Fellowship of the National Science Foundation during the work. 


\section{REFERENCES}

Argaman, M. \& Razin, S. (1965). Cholesterol and cholesterol esters in Mycoplasma. $J$. gen. Microbiol. 38, 153.

Cho, K. Y., Corpe, W. A. \& Salton, M. R. J. (1964). Effect of diphenylamine on the fatty acid composition of some bacterial lipids. Biochem. J. 93, 26 c.

Lowry, O. H., Rosebrough, N. J., Farr, A. L. \& Randall, R. J. (1951). Protein measurement with the folin phenol reagent. J. biol. Chem. 193, 265.

Morowitz, H. J., Tourtellotte, M. E., Guild, W. R., Castro, E., Woese, C. \& Cleverdon, R. C. (1962). The chemical composition and sub-microscopic morphology of Mycoplasma gallisepticum, avian PPLO 5969. J. molec. Biol. 4, 93.

Pollack, J. D., Razin, S. \& Cleverdon, R. C. (1965). Localization of enzymes in Mycoplasma. J. Bact. 90, 617.

Pollack, J. D., Razin, S., Pollack, M. E. \& Cleverdon, R. C. (1965). Fractionation of Mycoplasma cells for enzyme localization. Life Sciences, 4, 973.

RaziN, S. (1963). Structure, composition and properties of the PPLO cell envelope. Recent Progress in Microbiology, VIII, p. 526. Ed. by N. E. Gibbons. Toronto: University Press.

RAzIN, S. (1964). Factors influencing osmotic fragility of Mycoplasma. J. gen. Microbiol. 36, 451.

Razis, S. \& KNIGHT, B. C. J. G. (1960). A partially defined medium for the growth of Mycoplasma. J. gen. Microbiol. 22, 492.

Razin, S., Argaman, M. \& Avigan, J. (1963). Chemical composition of Mycoplasma cells and membranes. J. gen. Microbiol. 33, 477.

Razin, S., Morowitz, H. J. \& Terry, T. M. (1965). Membrane subunits of Mycoplasma laidlawii and their assembly to membrane-like structures. Proc. natn. Acad. Sci. U.S.A. 54, 219.

Rilling, H. C. (1965). A study of inhibition of carotenoid synthesis. Arch. Biochem. Biophys. 110, 39.

Rothblat, G. H. \& Sмiтh, P. F. (1961). Nonsaponifiable lipids of representative pleuropneumonia-like organisms. J. Bact. 82, 479.

Rothblat, G. H., Ellis, D. S. \& Kritchevsky, D. (1964). The carotenoid pigments of Micrococcus lysodeikticus. Biochim. biophys. Acta, 84, 340.

Smith, P. F. (1963a). The carotenoid pigments of Mycoplasma. J. gen. Microbiol. 32, 307.

Sмiтн, P. F. (1963b). The role of sterols in the growth and physiology of pleuropneumonialike organisms. Recent Progress in Microbiology, VIII, p. 518. Ed. by N. E. Gibbons. Toronto: University Press.

Smith, P. F. \& Henrikson, C. V. (1965). Glucose-containing phospholipids in Mycoplasma laidlawii, strain B. J. Lipid Res. 6, 106.

Tourtellotte, M. E., Jensen, R. G., Gander, G. W. \& Morowitz, H. J. (1963). Lipid composition and synthesis in the pleuropneumonia-like organism Mycoplasma gallisepticum. J. Bact. 86, 370. 